\title{
Financial Vulnerability, Capital Flow Reversals, and Divergence Macro-Prudential Policies Posing Challenges to the ASEAN Banking Integration Framework (ABIF)
}

\author{
Mohd Yaziz Mohd Isa \\ Universiti Tun Abdul Razak, Kuala Lumpur, Malaysia \\ Yap Voon Choong, David Yong Gunn Fie \\ Multimedia University, Selangor, Malaysia \\ Md. Zabid Haji Abdul Rashid \\ Universiti Tun Abdul Razak, Kuala Lumpur, Malaysia
}

\begin{abstract}
Against the prevailing background of an unusual capital flow reversal which is posing immense challenges to the integration of the region's banking sector, this study measures macro-prudential instruments affecting the implementation of an integrated financial service industry. This study is important at times when domestic and country-based financial policies are directed at competing goals. The interaction of macro-prudential policies with other policies, in particular monetary policies and micro-prudential policies is crucial to address systemic risk involved. There is growing recognition that prudential policies tools interact and coordinate with one another. To utilize multiple instruments seems to provide a greater assurance of effectiveness by tackling risk from various angles. As such, this study also assesses the interactions of the policies. The study also proposes a baseline model to capture systemic risk due to liquidity risk and risk because of currency devaluation.
\end{abstract}

Keywords: capital flow reversals, macro-prudential policies, ASEAN Banking Integration Framework (ABIF)

\section{Introduction}

The "Kuala Lumpur Declaration on ASEAN (the Association of Southeast Asian Nations) 2025" with a theme, "Forging Ahead Together", sets a direction for the ASEAN countries (the ten-member ASEAN bloc consisting of Indonesia, Malaysia, the Philippines, Singapore, Thailand, Brunei, Myanmar, Cambodia, Laos, and Vietnam) towards an integrated and connected economy, and the creation of a single economic market within the global economic system.

The "Kuala Lumpur Declaration" seeks to boost the region's economic growth by implementing the ASEAN Economic Community (AEC) from December 31, 2015. The establishment of the AEC aims to create freer capital flows and further deepening and integration of the region's banks. In the integration of the region's

Mohd Yaziz Mohd Isa, assistant professor, Bank Rakyat School of Business \& Entrepreneurship, Universiti Tun Abdul Razak. Email: mohd yaziz@unirazak.edu.my.

Yap Voon Choong, senior lecturer, Faculty of Management, Multimedia University.

David Yong Gunn Fie, associate professor, Faculty of Management, Multimedia University.

Md. Zabid Haji Abdul Rashid, president \& vice chancellor, Universiti Tun Abdul Razak. 
banking sector, the process is based on the "ASEAN Way" of consensus decision-making where each member country can take steps towards the integration if and when they believe to be ready. The flexible approach to achieving an integrated banking industry in the region will ensure ownership and incentive compatibility.

However, the implementation of the AEC is not without some uphill challenges. In particular, for an integrated banking sector, the potential for a long, drawn-out process with considerable risks involved. Intuitively, the ASEAN banking integration seemed to be under threat on all fronts coupled with challenges in measuring issues and designing research framework. In terms of capital flows for instance, presently the global banks are having a much bigger footprint than regional banks in the ASEAN countries. While there is no denying great strides made so far in liberalizing intra-ASEAN trade, they still remained very much inter-regional, i.e., from economies outside the region. The intra-ASEAN region accounts for only $25 \%$ of total trade according to the World Bank (2015) Annual Report (see Figure 1).

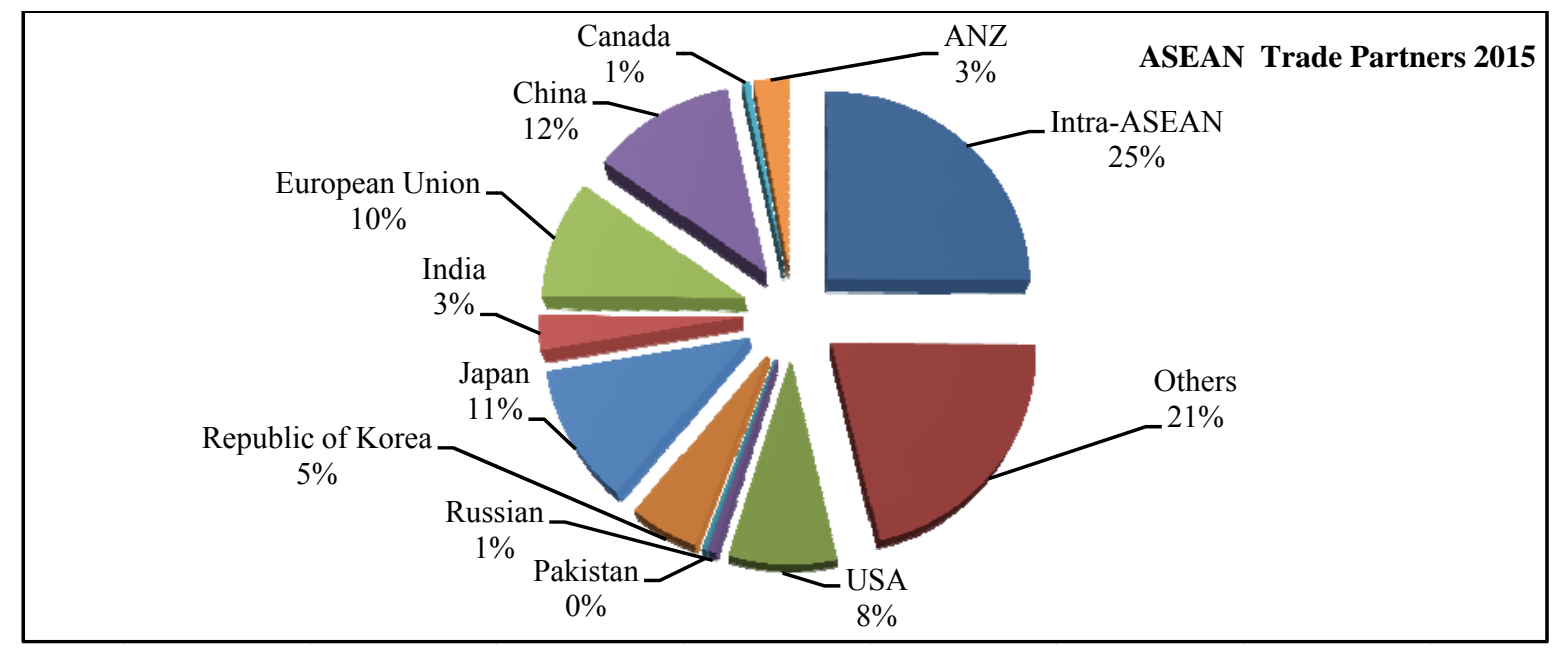

Figure 1. ASEAN trade partners 2015. Source: http://asean2015.gov.my/;

http://asean2015.gov.my/index.php/component/k2/item/21.html?Itemid=1361.

The ASEAN economies are currently experiencing an unusual cyclical capital flow reversal. The foreign funds are fledging the region's economies in search for higher yield. The weakening of the region's currencies and a slump in the global commodity prices weighting on the currencies of the region are not making the integration process any easy. For Malaysia, the previous chairman of the AEC, its currency, the Ringgit is depreciating in tandem with the decline in the crude oil prices owing to excess supply over demand.

Against the prevailing background of an unusual capital flow reversal which is posing immense challenges to the integration of the region's banking sector, a study to measure and assess macro-prudential instruments affecting the implementation of an integrated financial service industry is timely. This study is also important at times when domestic and country-based financial policies are directed at competing goals. In the case of Indonesia, a bank-based economy, its relatively shallow domestic financial market has the effect of accentuating the impact of global shocks more than in other ASEAN countries. In the case of Myanmar, the poorest among the ASEAN countries, its protracted transition of power after last year's general election is adversely affecting foreign capital flows into the country. This study is important also given the current developments in the local financial sector in these countries in response to the Global Financial Crisis of 2008, and the resultant uneven global recovery. 
Proactive policy response considerations in a number of areas such as efforts to improve regulatory environments and market infrastructures, and crisis prevention and resolution measures are therefore necessary. At the heart of such initiatives is to improve the resilience of the ASEAN financial system, a major component of the AEC framework.

In order to measure and assess the financial and regulatory cross-border spillovers effects on the ASEAN Banking Integration Framework (ABIF), this study uses the international banking and financial statistics compiled by the World Bank, the Bank for International Settlements (BIS) on behalf of the Committee on the Global Financial System (CGFS). This study also uses statistics compiled by the International Monetary Fund (IMF), the European Central Bank (ECB), and the ASEAN Development Bank (ADB) to supplement in the measurement and assessment analysis.

The interaction of macro-prudential policies with other policies, in particular monetary policies and micro-prudential policies is crucial to address systemic risk involved. There is growing recognition that prudential policies tools interact and coordinate with one another. To utilize multiple instruments seems to provide a greater assurance of effectiveness by tackling risk from various angles. As such, using a single instrument to tackle systemic risk is rare. The monetary policy should be aimed at price stability, to contain inflation, and sustainable employment, and it is confined over a horizon of no longer than two years. Meantime the latter are policies to improve the resilience of individual institutions. Intuitively, although these two policies target different policy objectives, they complement each other. Bruno, Shim, and Shin (2015) carried out a number of investigations into the effectiveness of macro-prudential policies in 12 Asia-Pacific economies. The authors suggested that the policies are successful when they complement monetary policy by reinforcing monetary tightening.

It is expected that the paper could assist policy makers and market participants to devise macro-prudential policies responses to ensure continuous provision of financial services, improve efficiency and credit availability. More importantly, it is expected that the policy responses would facilitate the process of the ASEAN-wide banking sector liberalization by 2020 as endorsed in April 2011 by the ASEAN Central Bank Governors. In addition, the study is also important because any responses to address the capital flow reversals may lead to subsequent slowdown of inflows into the ASEAN region in the next wave of such flows.

\section{Literature Review on Financial and Economic Integration}

\section{Differences in Banking Regulatory Frameworks}

Houston, Lin, and Ma (2012) studied the effects of regulatory arbitrage on international bank flows. The authors discovered that banks moved their funds to less regulated markets. The term, "race to the bottom" in the global regulations, is when governments deregulate their regulatory and financial policies to make their markets more attractive to outside financial interests or unattractive to unwanted outsiders. Bruno et al. (2015) in the assessment of macro-prudential policies have classified the movement of funds from one market to another attributed to cyclical forces rather than structural forces. The move by the banks to the less regulated markets allows them to circumvent the policies that may be unfavorable to them to continue to undertake the same activity. The adverse effect for the regulators is that it can restrict the regulators to monitor their risk-taking behavior. The authors added that the links between differences in regulatory frameworks and bank flows are more prevalent if the recipient country is with a matured financial system with strong property and legal rights, suggesting that while differences in regulatory frameworks have important influences, without a strong institutional quality is not enough to encourage capital flows. 
The above findings do not augur well for the banking sector in the ASEAN region presently at different phases of development. The indicators for financial stability and efficiency derived from the World Bank Report 2015 varied substantially among the ASEAN countries on "strength of legal right" and "depth of credit information" (see Table 1).

Table 1

ASEAN Countries: Financial Stability and Efficiency as Measured by Strength of Legal Right and Depth of Credit Information Index

\begin{tabular}{llcl}
\hline No. & Country & $\begin{array}{l}\text { Strength of legal rights index (2015) } \\
0-12 \text { (weak to strong) }\end{array}$ & $\begin{array}{l}\text { Depth of credit information index (2015) } \\
0-8 \text { (low to high) }\end{array}$ \\
\hline 1 & Brunei & 4 & 6 \\
2 & Cambodia & 11 & 5 \\
3 & Indonesia & 5 & 6 \\
4 & Lao PDR & 6 & 5 \\
5 & Malaysia & 7 & 7 \\
6 & Myanmar & 2 & 0 \\
7 & Philippines & 3 & 5 \\
8 & Singapore & 8 & 7 \\
9 & Thailand & 3 & 6 \\
10 & Vietnam & 7 & 7 \\
\hline
\end{tabular}

Notes. Strength of legal rights index measures the degree to which collateral and bankruptcy laws protect the rights of borrowers and lenders and thus facilitate lending. The index ranges from 0 to 12 , with higher scores indicating that these laws are better designed to expand access to credit. Depth of credit information index measures rules affecting the scope, accessibility, and quality of credit information available through public or private credit registries. The index ranges from 0 to 8 , with higher values indicating the availability of more credit information, from either a public registry or a private bureau, to facilitate lending decisions. Source: World Bank (http://wdi.worldbank.org/table/5.5).

Many previous studies have focused more on international bank flows in industrialized economies. The findings would have been far more useful to assess implications of on-going banking structural reforms among the ASEAN countries to provide insights into whether foreign investors still find the ASEAN market attractive.

Also, many studies have shown that during periods when banks' capital erodes, such as episodes of financial and economic distress, it bears riskiness of banks, and financial stability in general. Recent evidence suggests that banks may engage in riskier activities in an integrated market (Franklin, Carletti, \& Marquez, 2011). Thus, the differences in the regulatory frameworks critically determined the success of the ASEAN financial integration. This is because the differences might slow down the integration process. The argument was also highlighted by Houston et al. (2012). In the context of banks in ASEAN, a recent study by the Asian Banker Research Division in Singapore compiles a list of the Asia Pacific Banks Rankings including banks from the ASEAN region (see Table 2).

The ASEAN banking sector is at different stages of development. It cannot be denied that Singapore has the best established banking industry in the ASEAN region. The two top Singapore banks (OCBC Bank and United Overseas Bank) belong to the top 10 strongest banks by Balance Sheet in the Asia Pacific as ranked by the Asian Banker. The creation of the ASEAN banking integrated framework while providing more opportunities to well-capitalized and well-managed banks for greater regional access, but due to the different stages of development of the banks, may risk leaving some banks behind and further aggravating inequalities, if not managed effectively. As it is now in terms of productivity and efficiency, Bank Mizuho Indonesia is ranked 
number four in the Asia Pacific region. The ratio is commonly calculated by cost-to-income (CI) ratio: the ratio of total operating costs (excluding bad and doubtful debt charges) to total income (the sum of net interest and non-interest income) - and the lower the ratio, the more efficient is the banking sector as it can generate more income relative to its costs.

Table 2

ASEAN Banks Performance Rankings 2015 by Categories

\begin{tabular}{|c|c|c|c|}
\hline No. & Category & & \\
\hline \multirow[t]{4}{*}{1} & \multicolumn{3}{|l|}{ Asia Pacific strongest banks by balance sheet } \\
\hline & ASEAN country & ASEAN bank & Rank \\
\hline & Singapore & OCBC Bank & 2 \\
\hline & Singapore & United Overseas Bank & 7 \\
\hline \multirow[t]{3}{*}{2} & \multicolumn{3}{|l|}{ Asia Pacific bank largest growth in profit } \\
\hline & ASEAN country & ASEAN bank & Rank \\
\hline & Vietnam & Vietnam International Commercial Joint Stock Bank & 1 \\
\hline \multirow[t]{3}{*}{3} & \multicolumn{3}{|l|}{ Asia Pacific bank largest growth in deposit } \\
\hline & ASEAN country & ASEAN bank & Rank \\
\hline & Indonesia & Bank Syariah Mandiri & 2 \\
\hline \multirow[t]{5}{*}{4} & \multicolumn{3}{|l|}{ Asia Pacific bank highest return on assets } \\
\hline & ASEAN country & ASEAN bank & Rank \\
\hline & Indonesia & Bank Rakyat Indonesia & 1 \\
\hline & Indonesia & Bank Central Asia & 2 \\
\hline & Cambodia & ACLEDA Bank & 4 \\
\hline \multirow[t]{4}{*}{5} & \multicolumn{3}{|l|}{ Asia Pacific bank highest return on equity } \\
\hline & ASEAN country & ASEAN bank & Rank \\
\hline & Myanmar & Kanbawza Bank & 1 \\
\hline & Indonesia & HSBC (Indonesia) & 3 \\
\hline \multirow[t]{3}{*}{6} & \multicolumn{3}{|l|}{ Asia Pacific bank lowest cost to income ratio } \\
\hline & ASEAN country & ASEAN bank & Rank \\
\hline & Indonesia & Bank Mizuho Indonesia & 4 \\
\hline
\end{tabular}

By contrast, Bruno et al. (2015), by examining the effectiveness of capital controls of a banking sector, concluded that a less stringent control reduces the growth of the capital inflows.

While this study focuses on the effects of macro-prudential instruments on capital outflows, some of the macro-prudential instruments are considered capital control measures (CFM), in particular those that are designed to influence risks associated with capital flows. But not all capital flow measures are macro-prudential measures (and vice versa). It is a matter of careful judgment based on circumstances including whether the measures were introduced or intensified during an outflow surge - as currently experienced by the ASEAN economies - may be considered CFM.

Interestingly, growing openness to foreign capital flows underlies the economic freedom of a particular country. The Transparency International Corruption Perceptions Index (CPI) prepares its latest index of economic freedom of ASEAN countries (see Figure 2). Among the ASEAN countries, Cambodia scores 57.9 reflecting among others its "lack of structural reforms" and "poor protection of property rights". 


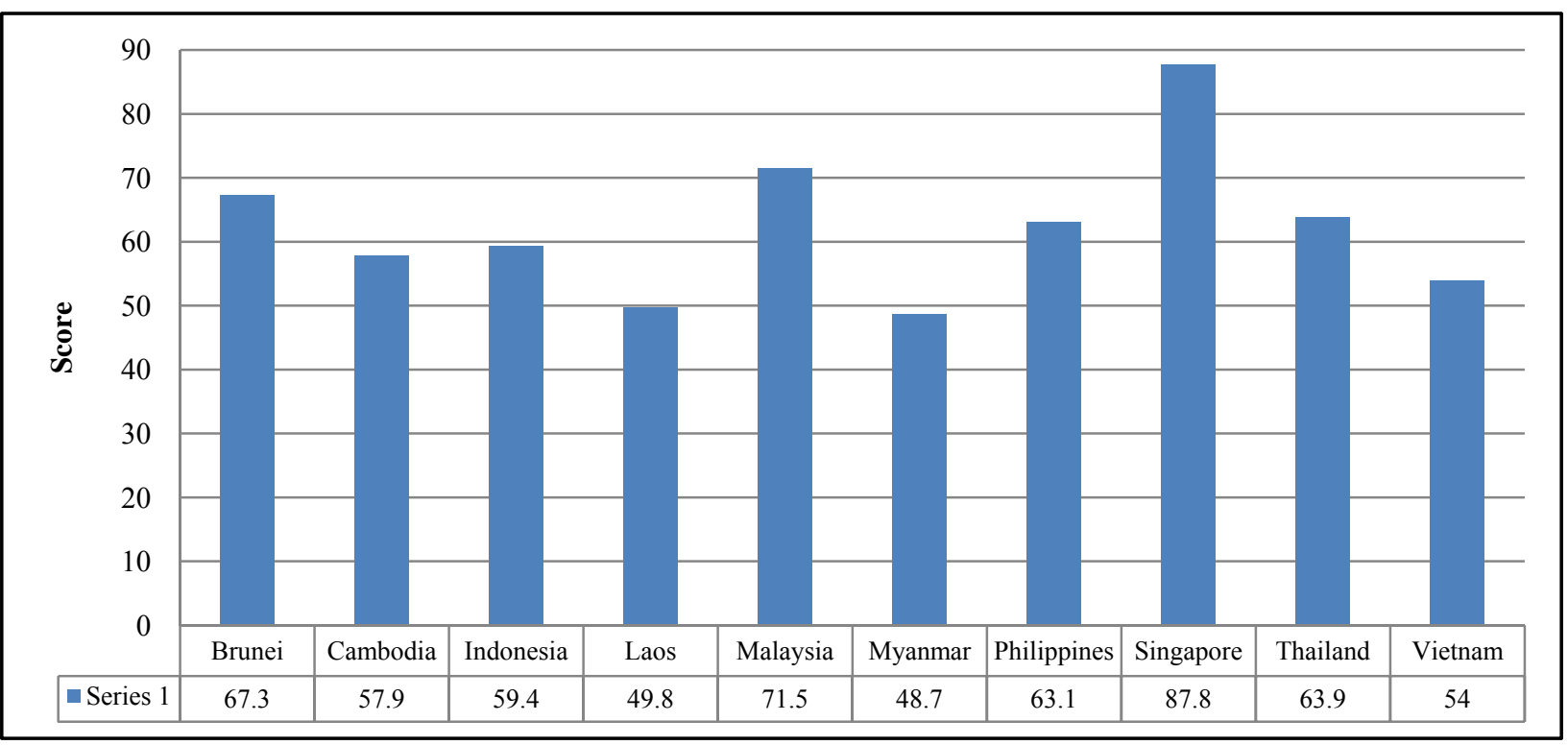

Figure 2. ASEAN countries 2016 index of economic freedom. Source: CARI Captures (2016).

In a similar work on bank leverage and risk-taking, Dell'Ariccia, Laeven, and Suarez (2013) constructed an ex-ante measurement by using loan data on the riskiness of loans to study the impact of low interest rates on bank risk-taking. In the study, they used ex-ante as it allows measurement of risk attitude of banks at the time a loan is issued rather than on ex-post loans performance which could be affected by subsequent events. The authors claimed that the general credit conditions have a bearing on bank risk-taking. Such expositions are timely in the present scenario of unusual surge of capital flows from the ASEAN economies to provide insights whether foreign investors are taking excessive risk when they pull out their funds from the ASEAN economies.

Based on the Asian Development Bank (2015), the ratios of non-performing loans among the ASEAN countries currently vary markedly (see Table 3 ). The integration of the ASEAN banking industry is expected to bring the ratio down to the same level due to shared resources and reduced information asymmetry costs in the loans markets.

Table 3

ASEAN Countries: Domestic Credit Provided by Banking Sector and Non-performing Loans

\begin{tabular}{|c|c|c|c|c|c|c|c|c|c|c|c|c|c|}
\hline \multirow[t]{2}{*}{ No. } & \multirow[t]{2}{*}{ Country } & \multicolumn{6}{|c|}{$\begin{array}{l}\text { Domestic credit provided by banking sector } \\
(\% \text { of GDP) }\end{array}$} & \multicolumn{6}{|c|}{$\begin{array}{l}\text { Bank non-performing loans } \\
\text { (\% of total gross loan) }\end{array}$} \\
\hline & & 1990 & 1995 & 2000 & 2005 & 2010 & 2014 & 2000 & 2005 & 2010 & 2012 & 2013 & 2014 \\
\hline 1 & Brunei & - & - & 38.6 & 10.4 & 25.1 & 25.3 & - & - & 6.9 & 5.4 & 4.5 & 3.7 \\
\hline 2 & Cambodia & - & 5.3 & 6.4 & 7.2 & 22.7 & 47.4 & - & - & - & - & - & - \\
\hline 3 & Indonesia & 47.6 & 51.8 & 60.7 & 46.2 & 34.2 & 48.4 & 34.4 & 7.3 & 2.5 & 1.8 & 1.7 & 2.1 \\
\hline 4 & Lao PDR & 5.0 & 9.9 & 9.0 & 8.1 & 26.5 & - & - & - & - & - & - & - \\
\hline 5 & Malaysia & 72.7 & 126.7 & 138.4 & 117.7 & 127.0 & 145.3 & 15.4 & 9.4 & 3.4 & 2.0 & 1.8 & 1.6 \\
\hline 6 & Myanmar & 39.6 & 32.5 & 31.2 & 24.6 & 24.8 & 28.3 & - & - & - & - & - & - \\
\hline 7 & Philippines & 23.2 & 55.7 & 58.3 & 47.2 & 49.2 & 55.9 & 24.0 & 10.0 & 3.4 & 2.2 & 2.4 & 2.0 \\
\hline 8 & Singapore & 58.6 & 59.1 & 76.7 & 61.2 & 80.8 & 126.3 & 3.4 & 3.8 & 1.4 & 1.0 & 0.9 & 0.8 \\
\hline 9 & Thailand & 94.1 & 141.3 & 138.3 & 119.2 & 142.7 & 182.5 & 17.7 & 9.1 & 3.9 & 2.4 & 2.3 & 2.5 \\
\hline 10 & Vietnam & - & 20.1 & 32.6 & 65.4 & 124.7 & 113.8 & - & - & 2.1 & 3.4 & 3.4 & - \\
\hline
\end{tabular}

Note. Source: Asian Development Bank (2015, p. 266). 
For foreign banks, however, Ongena, Popov, and Udell (2013) demonstrated that they increase their risk-taking activity in foreign markets they are in soon after stricter regulations are imposed in their home markets. The reason for this is that they make up for the inability to take on risk in the home markets, the authors explained. Therefore, it is becoming increasingly difficult not to agree that regulatory framework not only determines the success of the ASEAN banking integration but also can have far-reaching implications on banking activities of foreign banks in the region.

Many studies also provide convincing evidences on how reformed regulatory frameworks are important in the banking integration process. Reinhardt and Sowerbutts (2015) observed that foreign banks responded to a decline in lending by reference group - the domestic banks - by increasing their business activity in host-country following an action which tightened capital requirements in the home country. In response to tightening of lending standards, there was no increase in the business activity, the authors discovered. Hale and Arteta (2009) divided the reasons for the decrease in business activity into credit crunch implying the cost of credit prohibitively high from the decrease due to a reduction in demand for credit. In both groups, the authors showed the resultant large scale of economic downturns as well as the decline in investment activity.

Similarly, Ongena et al. (2013) found that multi-national banks increase risk-taking activity in the foreign markets they are in following stricter banks regulations in home country markets. The reason for this was that they made up for the inability to take on risk in the home country markets. A number of related studies also examine the effect of regulatory measures on the behavior of banks subject to the measures, such as the effect on provision of credit. More recently, Aiyar, Calomiris, and Wieladek (2012) found that foreign banks in the United Kingdom increased lending in response to a regulation-induced decline in lending by the domestic banks. In order to focus on the effect of bank risk from subsequent events resulted from rapid outflows in foreign capital, this paper proposes an examination of ex-post loan performance to be based on loan default rates. However, in practice, the existence of cross-country differences in banking regulations is still an issue among the ASEAN economies. Therefore, because the regulations and supervision are national, any generalization of the conclusion is sill problematic.

As it is, currently there is yet a single agreement that would mandate reciprocity for the financial service industry in the ASEAN region. But work is already underway for a bilateral reciprocity agreement on cross-border market access through Qualified ASEAN Banks (QABs) platform. It will allow for banks to operate in other ASEAN countries on the same terms as domestic financial institutions. While the full ASEAN banking integration is in 2020, under the current timeframe, each ASEAN country should have at least one QAB bank ready by 2018 for regional integration. An implication of this is the possibility that the frameworks would support businesses that wish to expand their operations into other ASEAN countries.

The ASEAN regulators can learn from the experience of the European countries that succeeded to integrate the banking sector. During the integration process, the European countries fostered reciprocity through the spirit of "comply or explain" powers. All banks in the European Union conducting a particular activity were subjected to the same macro-prudential instruments irrespective of the bank's home country. However, for the ASEAN economies, there are added challenges for the regulators to come to an agreement on what sets of common criteria for the ASEAN banks to meet for reciprocal access to be granted. Not only because of the absence of national prudential policies, but also because of the existence of new forms of finance. Not surprisingly, Reinhardt and Sowerbutts (2015) further raised potential risks of leakage to activity not covered by existing regulations such as, "shadow banks" or non-bank financial institutions. Over the past 
decade, financial intermediation has undergone important changes in new forms of finance through debt securities markets. The new forms (of finance) replace bank lending in emerging markets including the Asean markets according to Mohanty (2015).

\section{Divergence in Macro-prudential Instruments}

While the AEC seeks to enhance and foster an open, inclusive, and market-driven economy, from the banking industry regulatory point of view, existing divergence in macro-prudential frameworks poses immense challenges. The different financial landscapes underlie the diversity of macro-prudential frameworks. They are attributed to the fact that each ASEAN country has its own sets of prudential regulations governing various forms of banking activity. In the past decade, the ASEAN countries have instituted various forms of the prudential regulations (see Table 4).

Table 4

Frequency of Macro-prudential Measures Taken by ASEAN Economies Over 2004-2013

\begin{tabular}{|c|c|c|c|c|c|c|c|c|c|c|}
\hline \multirow{2}{*}{ No. } & \multirow{2}{*}{ Country } & \multicolumn{3}{|c|}{ Monetary measures } & \multicolumn{3}{|c|}{ Prudential measures } & \multicolumn{3}{|c|}{ All macro-prudential measures } \\
\hline & & Tighten & Loosen & Total & Tighten & Loosen & Total & Tighten & Loosen & Total \\
\hline 1 & Brunei & $\mathrm{n} / \mathrm{a}$ & $\mathrm{n} / \mathrm{a}$ & $\mathrm{n} / \mathrm{a}$ & $\mathrm{n} / \mathrm{a}$ & $\mathrm{n} / \mathrm{a}$ & $\mathrm{n} / \mathrm{a}$ & $\mathrm{n} / \mathrm{a}$ & $\mathrm{n} / \mathrm{a}$ & $\mathrm{n} / \mathrm{a}$ \\
\hline 2 & Cambodia & $\mathrm{n} / \mathrm{a}$ & $\mathrm{n} / \mathrm{a}$ & $\mathrm{n} / \mathrm{a}$ & $\mathrm{n} / \mathrm{a}$ & $\mathrm{n} / \mathrm{a}$ & $\mathrm{n} / \mathrm{a}$ & $\mathrm{n} / \mathrm{a}$ & $\mathrm{n} / \mathrm{a}$ & $\mathrm{n} / \mathrm{a}$ \\
\hline 3 & Indonesia & 2 & 1 & 3 & 1 & 0 & 1 & 3 & 1 & 4 \\
\hline 4 & Lao PDR & $\mathrm{n} / \mathrm{a}$ & $\mathrm{n} / \mathrm{a}$ & $\mathrm{n} / \mathrm{a}$ & $\mathrm{n} / \mathrm{a}$ & $\mathrm{n} / \mathrm{a}$ & $\mathrm{n} / \mathrm{a}$ & $\mathrm{n} / \mathrm{a}$ & $\mathrm{n} / \mathrm{a}$ & $\mathrm{n} / \mathrm{a}$ \\
\hline 5 & Malaysia & 2 & 3 & 5 & 4 & 0 & 4 & 6 & 3 & 9 \\
\hline 6 & Myanmar & $\mathrm{n} / \mathrm{a}$ & $\mathrm{n} / \mathrm{a}$ & $\mathrm{n} / \mathrm{a}$ & $\mathrm{n} / \mathrm{a}$ & $\mathrm{n} / \mathrm{a}$ & $\mathrm{n} / \mathrm{a}$ & $\mathrm{n} / \mathrm{a}$ & $\mathrm{n} / \mathrm{a}$ & $\mathrm{n} / \mathrm{a}$ \\
\hline 7 & Philippines & 6 & 3 & 9 & 0 & 1 & 1 & 6 & 4 & 10 \\
\hline 8 & Singapore & 0 & 0 & 0 & 9 & 1 & 10 & 9 & 1 & 10 \\
\hline 9 & Thailand & 1 & 2 & 3 & 3 & 1 & 4 & 4 & 3 & 7 \\
\hline 10 & Vietnam & $\mathrm{n} / \mathrm{a}$ & $\mathrm{n} / \mathrm{a}$ & $\mathrm{n} / \mathrm{a}$ & $\mathrm{n} / \mathrm{a}$ & $\mathrm{n} / \mathrm{a}$ & $\mathrm{n} / \mathrm{a}$ & $\mathrm{n} / \mathrm{a}$ & $\mathrm{n} / \mathrm{a}$ & $\mathrm{n} / \mathrm{a}$ \\
\hline
\end{tabular}

Note. Source: Table 5 in Bruno et al. (2015, p. 42); BIS Quarterly Review.

An implication of differing macro-prudential policies is that an extended time is needed by its member countries to prepare and consolidate their respective banking systems. Astriana (2015) warned potential systemic banking crises for the reason of an extended time. Caprio and Klingebiel (2003) defined systemic banking crises as much or all of bank capital being exhausted. In addition to the potential of systemic banking crises, Almekinders, Fukuda, Mourmouras, and Zhou (2015) warned of potential contagion and spillovers risks owing to catching up by the less developed countries from among the ASEAN countries. This arises from an uneven playing field from among the ASEAN countries. Henceforth, an additional time is needed by the ASEAN countries for preparation and consolidation works to complete.

\section{Diversity of Stages and Pace of Economic and Financial Development}

In recent years, there has been an increasing interest in measuring the relationship between foreign direct investment (FDI) inflows and economic growth. The relationship between the two indicators is largely established in empirical work. Iamsiraroj and Doucouliagos (2015) examined the impact of economic growth on FDI inflows. The authors found the correlation between economic growth and FDI inflows to be positive and significant, and that it is slightly higher in the case of developing countries. Figure 3 shows the proportion of FDI distribution in ASEAN countries from 2010 to 2014 (in \%). 


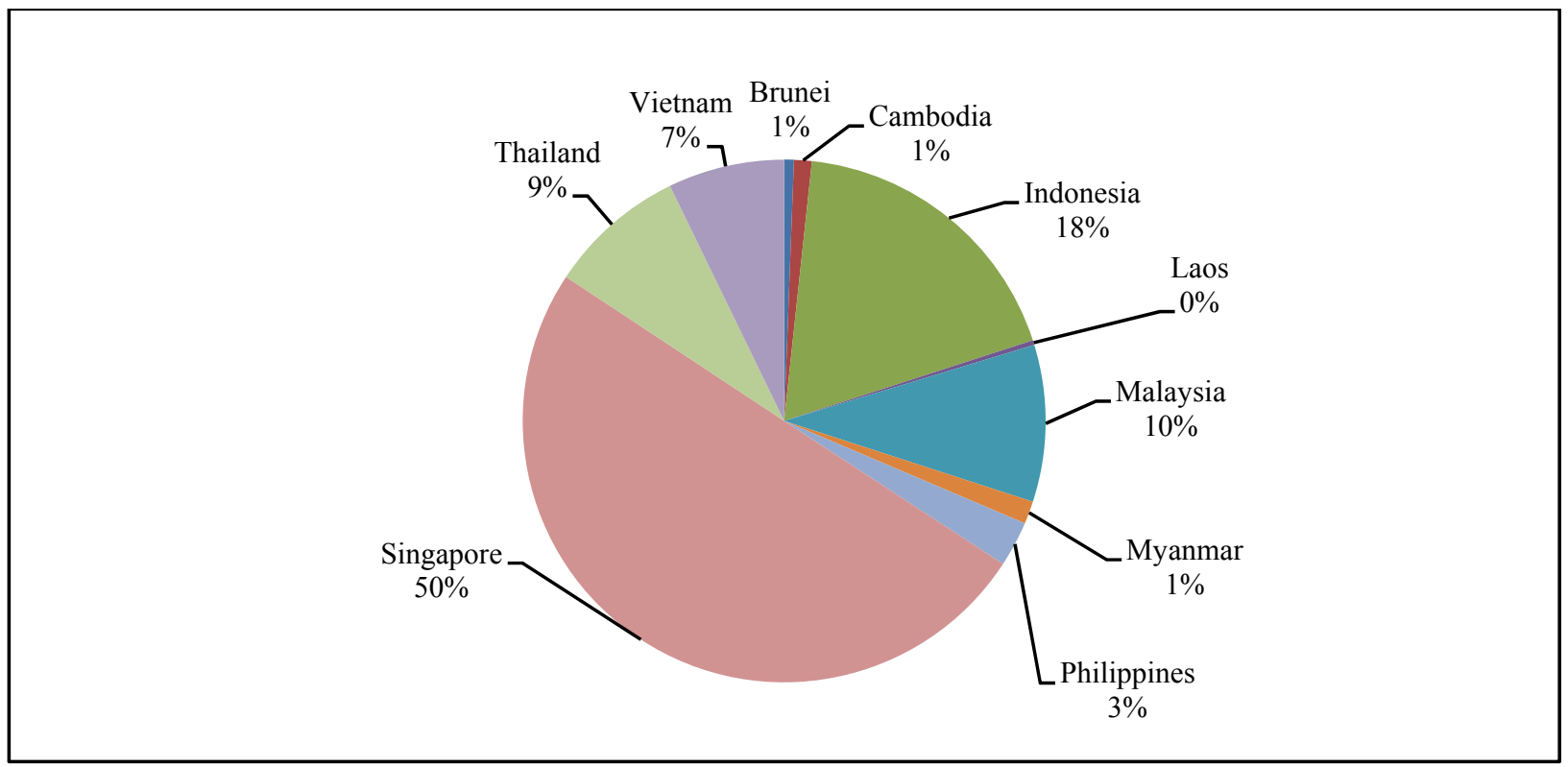

Figure 3. Proportion of FDI distribution in ASEAN countries in the period of 2010-2014 (\%). Source: The World Bank.

However, when a comparison of the proportion of FDI inflows to GDP is carried out, a different picture emerges. The results of the comparison of the proportion of FDI inflows to GDP of the ASEAN countries show that, unlike for Singapore, there is still much room for attracting incoming FDI for economic growth for other ASEAN countries (see Figure 4).

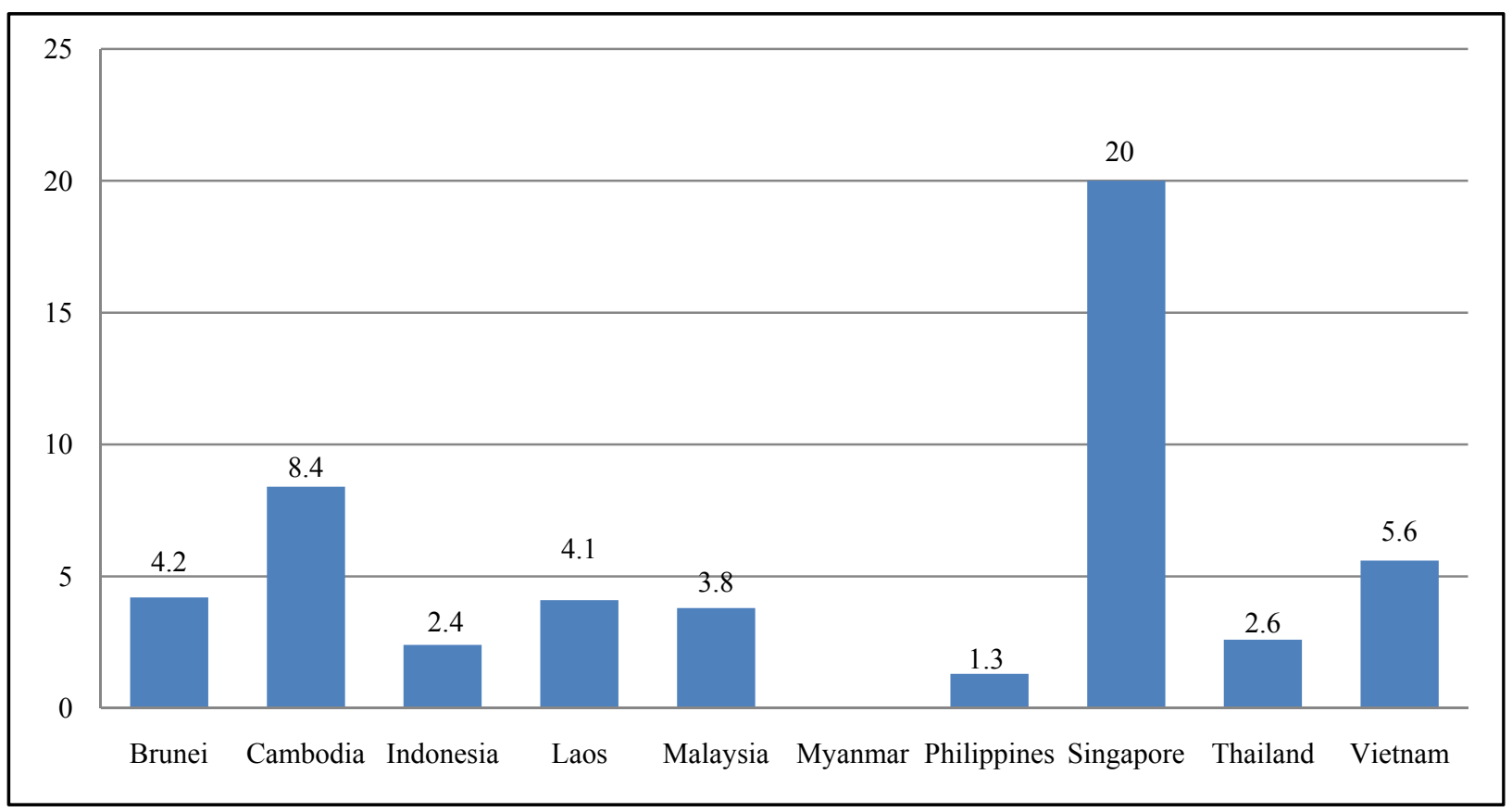

Figure 4. Average proportion of FDI to GDP in the period of 2010-2014 (\%). Source: The World Bank.

But looking at the declining trends in FDI inflows into the ASEAN economies, it seems to be imposing a serious threat on the economic growth and the banking sector integration process (see Figure 5). 

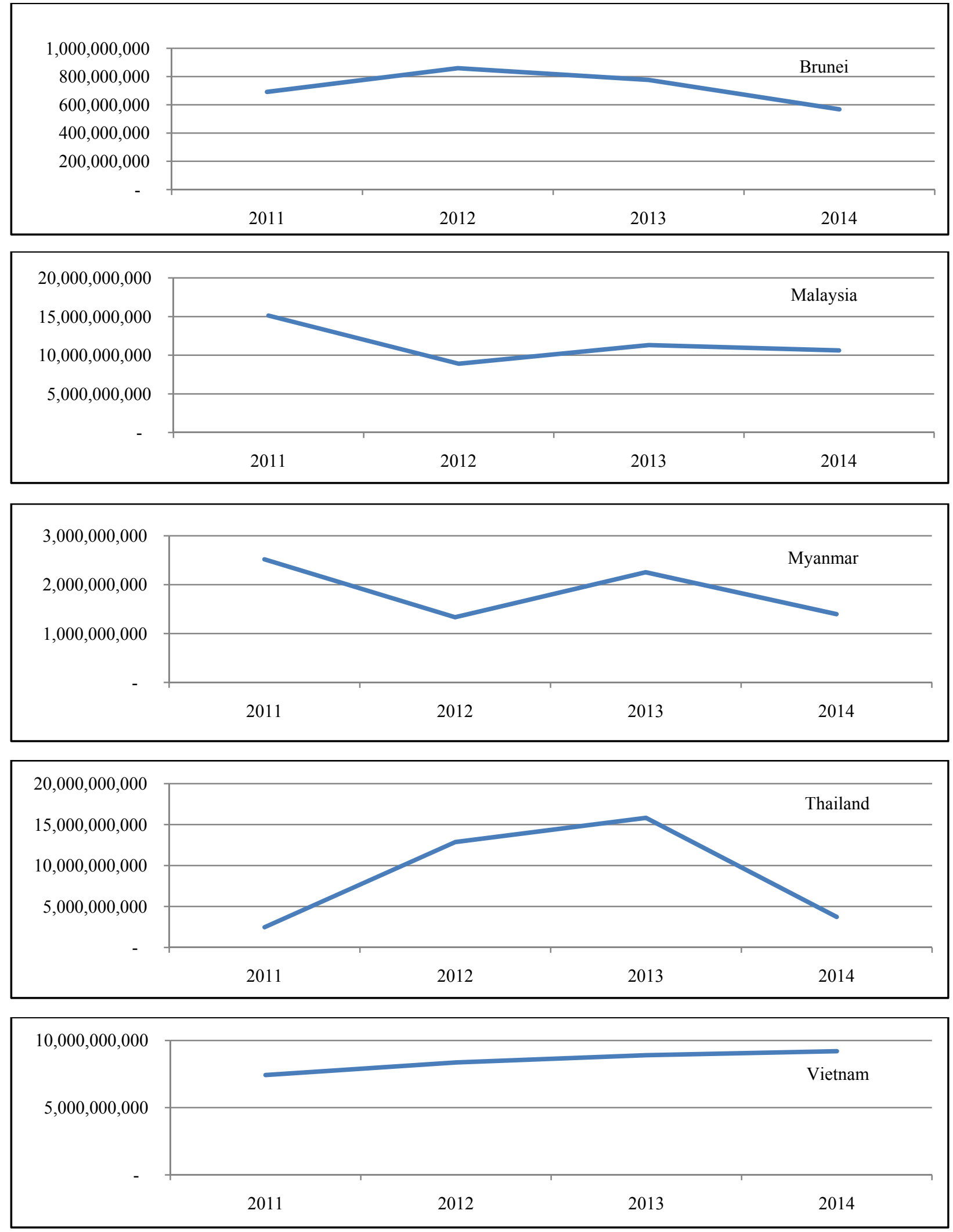

Figure 5. Selected ASEAN countries' FDI net inflows (Current US\$). Source: The World Bank Foreign Direct Investment Net Inflows (Current US\$). 
For the ASEAN countries, embarking on an integrated banking system, while not having all the necessary financial infrastructure works in place to tackle the risks due to cross-border financial contagion effects, would pose a banking crisis, especially for the less developed among the countries that are catching up, as Almekinders et al. (2015) argued. It is interesting to note, in the existing criteria on eligibility for the World Bank assistance, as of June 30, 2015, not all ASEAN countries are eligible for financial assistance from the World Bank (see Table 5).

Table 5

ASEAN Countries' Eligibility for the World Bank Assistance

\begin{tabular}{|l|l|l|}
\hline No. & Country & Eligible $(\sqrt{ })$ as of June 30, 2015 \\
\hline 1 & Brunei & Not eligible \\
\hline 2 & Cambodia & $\sqrt{ }$ \\
\hline 3 & Indonesia & $\sqrt{ }$ \\
\hline 4 & Lao PDR & $\sqrt{ }$ \\
\hline 5 & Malaysia & $\sqrt{ }$ \\
\hline 6 & Myanmar & $\sqrt{ }$ \\
\hline 7 & Philippines & $\sqrt{ }$ \\
\hline 8 & Singapore & Not eligible \\
\hline 9 & Thailand & $\sqrt{ }$ \\
\hline 10 & Vietnam & $\sqrt{ }$ \\
\hline
\end{tabular}

Note. Source: The World Bank (2015, p. 35) Annual Report (“ $\sqrt{ }$ ” Eligible).

The different status of the eligibility for the financial assistance from the World Bank also underlies the differences in the levels of Gross National Income (GNI) in current USD among the ASEAN countries from 1988 to 2014 (see Figure 6).

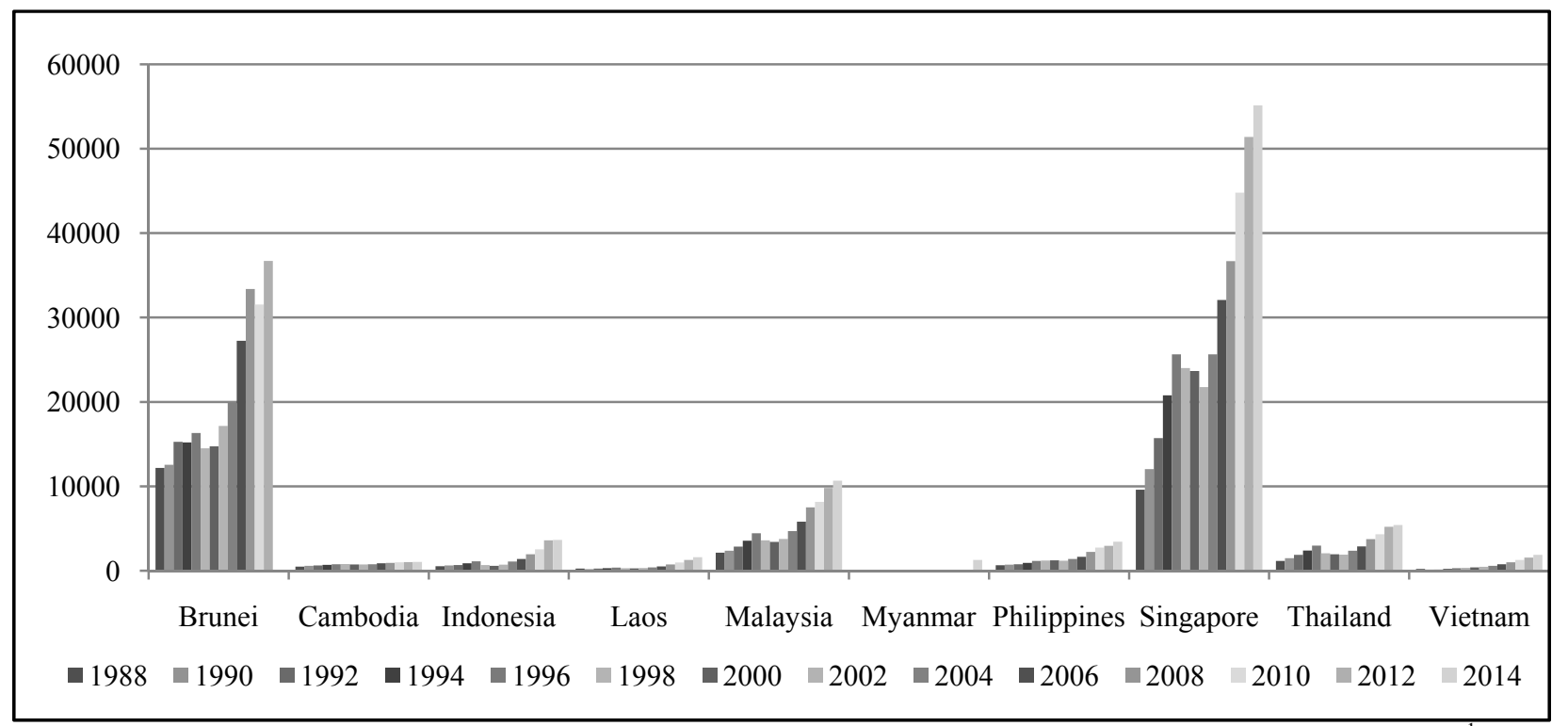

Figure 6. ASEAN countries' GNI per capita trends in the period of 1988-2014. Source: Fantom and Serajuddin (2016) ${ }^{1}$.

\footnotetext{
1 The World Bank Development Report on measurement of economic development on GNI per capita 1988-2014 prepared by Fantom and Serajuddin (2016). In the report, the groupings in the latest report of "low income", "middle income" countries also incorporate those countries that are not industrialized, surplus oil producers, or centrally planned adjusted the threshold for inflation in each year.
} 
Each ASEAN country is at its own pace of development, for instance, Thailand's economic growth continued to slow - falling to $0.9 \%$ in 2014 from $2.8 \%$ in 2013 (and from $7.1 \%$ in 2012) amid declining tourism receipts and investment (Asian Development Bank, 2015, p. 222). However, Moshirian and Wu (2009) noted the differences in the level of economic development on the determinants of banking crises. In their detailed examination on banking crises, the authors concluded that developed markets could have different causes of systemic banking crises from the emerging markets. While acknowledging that the identification of the episodes and dates of banking crises is somewhat arbitrary, the authors further suggested that the leading indicators of the crises tend to be more country-specific depending on factors. The factors include, inter alia, the quality of supervision, phase of the credit cycle in which the tools are implemented, the extent to which circumvention and arbitrage are possible, the ability of the authorities to take coordinated policy actions to limit circumvention, and their responsiveness to changed conditions, according to Lim, Columba, Costa, Kongsamut, Otani, Saiyid, Wezel, and Wu (2011).

\section{Differences in Interest Rates}

Apart from the subdued regional economic growth, a key aspect of the successful ASEAN banking integration is the profitability and debt servicing capability of the banking sector. In light of this, the ASEAN financial regulators responsible to oversee the integration process have to critically assess whether the process would translate into excessive risk-taking by the banks in the region. The regulators can learn from the discovery made by Goldstein and Turner (1996) of the Monetary and Economic Department at the BIS in 1996. Based on the experience of the emerging economies, the authors discovered the more volatile environment in which banks operate, the more banking flows in the banking system. Interestingly, they concluded that the main contributor for banking fragility in emerging economies was due to external debt which was susceptible to volatility in exchange rates. In a related study, Reinhardt and Sowerbutts (2015) later reinforced this notion when they too observed that emerging markets are more active in using macro-prudential regulations to manage lending risks due to changes in foreign currency exchange rates.

Presently, the interest rate spread - interest rate charged by banks on loans minus the interest rate paid for deposits among the ASEAN member states - diverges widely (see Table 6).

Table 6

ASEAN Countries: Interest Rate Spread by Country

\begin{tabular}{llllll}
\hline \multirow{2}{*}{ No. } & Country & \multicolumn{4}{c}{ Interest rate spread by country } \\
\cline { 3 - 6 } & 2011 & 2012 & 2013 & 2014 \\
\hline 1 & Brunei & 5.1 & 5.3 & 5.2 & 5.2 \\
2 & Cambodia & - & - & - & - \\
3 & Indonesia & 5.5 & 5.8 & 5.4 & 3.9 \\
4 & Lao PDR & - & - & - & - \\
5 & Malaysia & 2.0 & 1.8 & 1.6 & 5.0 \\
6 & Myanmar & 5.0 & 5.0 & 5.0 & 4.3 \\
7 & Philippines & 3.3 & 2.5 & 4.1 & 5.2 \\
8 & Singapore & 5.2 & 5.2 & 5.2 & 4.8 \\
9 & Thailand & 4.6 & 4.3 & 4.1 & 2.9 \\
10 & Vietnam & 3.0 & 3.0 & 3.2 & \\
\hline
\end{tabular}

Note. Source: World Bank Group (Retrieved from http://data.worldbank.org/indicator/FR.INR.LNDP). 
According to Were and Wambua (2014), the spread is influenced by bank-specific factors such as size, levels of non-performing loans, return on average assets, and operating costs. And, according to the authors, higher interest rate spreads are indicators of an inefficient financial intermediation. In the implementation of an ASEAN banking integration, there is a need to narrow down the lending spreads. The responsibility lies within the ASEAN banking community as a whole and the individual banks in ASEAN to explore internally and industry-driven strategies to address some of the bank-specific factors that resulted in wide differences in interest spread. Hmili and Bouraoui (2015), in their study on early indicators of banking crisis in emerging countries, stated that differences in interest rates are common among the ASEAN banks. From their study on early indicators of banking crisis in emerging countries, Hmili and Bouraoui (2015) discovered the common reason was that of differences in interest rates of the banks.

The lending rates differentials among the ASEAN member states also remained markedly wide. Lending rates are rates that usually meet the financing needs of the private sector. Malaysia has the lowest lending rate of $4.6 \%$ as Table 7 shows. It would be a challenge to drive down lending rates among the ASEAN countries to comparable levels from increased competition. The wide differences in the rates among the ASEAN countries reflect the wide differences in levels of effectiveness of not only the banking industry but also the monetary policy among the countries. Put differently, the wide differences in the bank lending rates reflect the wide differences of their speeds of adjustment to the monetary policy. Matemilola, Bany-Ariffin, and Muhtar (2015) carried out a number of investigations on transmission of money market rate to bank lending rate in the South African banking sector. Interestingly, they discovered that the speed of adjustments is not uniform during periods of expansion and contraction of monetary policy.

Table 7

ASEAN Countries: Lending Rates

\begin{tabular}{llcc}
\hline \multirow{2}{*}{ No. } & Country & \multicolumn{2}{c}{ Lending rate by country } \\
\cline { 3 - 4 } & & 2013 & 2014 \\
\hline 2 & Brunei & 5.5 & 5.5 \\
3 & Cambodia & - & - \\
4 & Indonesia & 11.7 & 12.6 \\
5 & Lao PDR & - & - \\
6 & Malaysia & 4.6 & 4.6 \\
7 & Myanmar & 13.0 & 13.0 \\
8 & Philippines & 5.8 & 5.5 \\
9 & Singapore & 5.4 & 5.4 \\
10 & Thailand & 7.0 & 6.8 \\
\hline
\end{tabular}

Note. Source: World Bank Group (Retrieved from http://data.worldbank.org/indicator/FR.INR.LEND/countries).

However, there is more recent evidence that international spillovers from unconventional monetary policies - which aim to maintain stability in exchange rates with other currencies, transmitting to bank lending rates, and to a greater extent, they control inflation and to achieve economic growth - have yielded greater benefits to emerging economies, as Reinhardt and Sowerbutts (2015) concluded. In a related study, Kalemli-Ozcan, Papaioannou, and Perri (2013) pointed to the benefits of ASEAN regional banking integration that could reduce the impact of financial shocks originating in advanced countries. 
From a competing perspective, Jeanne (2014) in her analysis on global analysis of macro-prudential policies concluded that cross-border coordination may be justified only if there is global demand shortage when the case is stronger in the bust, when global resources are underutilized, than in a boom. Since there is continuing divergence in Asian and the global GDP, this needs to be looked at in the assessment of the integration of the ASEAN banks.

\section{Proposed Baseline Model to Measure “Capital Flow Reversals”}

In this study, the availability of comprehensive data from various sources - the World Bank, the BIS, the IMF, the ECB, and the ADB - allows examining the relation between bank regulation and institutional quality in source countries and capital outflows for each year; therefore, the dependent variable in the regression equation is the "capital outflow".

In the evaluation, data availability and quality present challenges. Since macro-prudential instruments are aimed at the balance sheet of banks, bank level data are preferable. To be considered are macro-prudential measures that come into being following a sudden surge in capital outflows from the ASEAN region. Through exploration of the significance of capital outflows from the ASEAN economies, it allows making headway on a very fundamental question - the cross-border spillovers effects in the ASEAN economies posing challenges to the implementation of the ABIF. It is hoped to guide policy advice in surveillance and technical assistance:

$$
\text { Capital Outflows }_{s, t}=\text { Bank Regulation }_{s, t}+\text { Institutional Quality }_{s, t}
$$

As the baseline model captures the ASEAN banks" capital outflows (thus " $s$ " = source) of 10 ASEAN countries. The regression equation captures the factors influencing the capital outflows from banks in ASEAN countries.

It is important for the panel regressions to also include country-fixed effects because the ASEAN countries implement selective prudential measures at different times. There are time series variations in this study so that we can identify the impact of such measures. In the regression Equation (1), $s$ and $t$ indicate ASEAN countries as the source country ( $s=$ ASEAN countries), and $t=$ time (year), respectively.

$$
\text { Capital Outflows }_{s=A s e a n, t}=\text { Bank Regulation }_{s=\text { Asean }, t}+\text { Institutional Quality }_{s=A s e a n, t}
$$

For the regression equation, it is constructed as 100 times the log-difference of total foreign claims (FCsr) from 10 ASEAN countries " $s$ ".

\section{Selected Macro-prudential Policies}

The comprehensive nature of database allows selecting macro-prudential measures that are economically important currently confronting the financial stability of the ASEAN countries for the regression equation. Given that capital reversal flows and depreciation of the region's currencies are central to the ASEAN economies, there are compelling evidences that two broad categories of systemic risks are applied as they incorporate micro-prudential instruments. The two systemic risks are:

(1) Systemic liquidity risk;

(2) Risks related to large and volatile capital flows, and currency devaluation.

A detailed examination of effectiveness of macro-prudential policies among 49 countries over 10 years from 2000 to 2010 by Lim et al. (2011) showed that emerging economies more concerned about systemic liquidity risk and tend to prefer liquidity-related risk. Also, the authors demonstrated that the economies 
considered financial shocks arose from capital flows to be of significant impact given the size of their economy and the degree of openness.

Even though the use of macro-prudential policies is idiosyncratic across ASEAN countries, where even policies which sound similar vary in their implementation, and similarly risks weights often differ across ASEAN countries making measuring, assessing, and calibrating the instruments difficult, because of similarity in the effects of financial shocks confronting the economies, the micro-prudential policies to mitigate the two categories of systemic risk as listed are compelling enough (see Table 8).

Table 8

Two Categories of Systemic Risk

\begin{tabular}{|c|c|c|c|}
\hline No. & Target risk variables & Tools & Examples of macro-prudential tools \\
\hline 1 & Systemic liquidity risk & Liquidity-related tools & $\begin{array}{l}\text { Limits on maturity mismatch: } \\
\text { Credit/deposit can be used as a proxy for wholesale funding in the } \\
\text { estimation of the effectiveness of limits on maturity mismatch. It is intended } \\
\text { to see if this instrument limits wholesale funding, considered a source of a } \\
\text { systemic risk with a cross-sectional dimension. In a crisis, the inability of a } \\
\text { bank to meet its obligations may be due to maturity mismatches. And the } \\
\text { funding shortages of a few banks could also result in a systemic liquidity } \\
\text { crisis due to the contagion effect. }\end{array}$ \\
\hline 2 & $\begin{array}{l}\text { Risk related to large } \\
\text { and volatile capital } \\
\text { flows/currency } \\
\text { fluctuation }\end{array}$ & $\begin{array}{l}\text { Capital-related } \\
\text { measures }\end{array}$ & $\begin{array}{l}\text { Limit on currency mismatch/net open currency position: } \\
\text { External indebtedness (foreign liabilities/foreign assets) can be used as a proxy } \\
\text { for common exposure to risks associated with capital flow reversals risk. } \\
\text { Net open positions (NOP) in foreign currency can be used to address an } \\
\text { externality, to measure the financial sector's dependence on foreign sources } \\
\text { of funding. }\end{array}$ \\
\hline
\end{tabular}

Note. Source: IMF Financial Stability and Macro-prudential Policy Survey 2010. Lim et al. (2011, p. 9).

The preferred specification is to use dummy variables in the analysis. Dummy variables for factors such as the degree of economic development, the type of exchange regimes, and the size of the financial sector are used to infer the general effect if the instruments are effective across countries. The capital outflow is coded in the form of a dummy variable which takes the value of 1 if there has been such outflows from ASEAN countries and 0 if otherwise.

Reinhardt and Sowerbutts (2015) of the Bank of England drew our attention to the fact that it would be during financial crisis that monetary policy and macro-prudential measures took the same course either in tightening or loosening the effects of policies. Most countries during financial crises loosened their policies to stimulate growth, the authors concluded. Turning to the interaction of monetary policy and macro-prudential measures, Bruno et al. (2015) concluded that macro-prudential measures are more effective to complement monetary policies by reinforcing monetary tightening. The authors arrived at this conclusion based on their observations of macro-prudential policies implemented in 12 Asia-Pacific countries over 2004-2013. This is supported by Zdzienicka, Chen, Kalan, Laseen, and Svirydzenka (2015), whose working paper traces monetary and macro-prudential policies in the United States from 1969 to 2008. The authors discovered that tightening measures tend to display larger effects than loosening ones. Moreover, the effects tend to be larger during economic recessions than during economic expansions. More importantly, the paper critically examines much greater effects of US monetary policy for emerging economies that rely on foreign capital. It is timely to study the effectiveness of prudential policies in order to shed some lights as the ASEAN countries are currently experiencing massive capital flow reversals. From observation of the effectiveness of macro-prudential policies in 49 countries during a 10-year period from 2000-2010, Lim et al. (2011) demonstrated that the effectiveness of 
the policies depends on the shocks facing the financial sector. This study is timely in view of the current scenario of massive capital flow reversals facing the ASEAN economies. The capital flight darkens economic prospects for the ASEAN economies and subjected them all the more vulnerable. Turning now to spillover effects of macro-prudential policies on financial sector, Zdzienicka et al. (2015) discovered that the spillover impact is larger for emerging economies which rely on foreign capital. Notwithstanding varying impacts of the policy depending upon country-specific characteristics, factors such as financial integration and linkages through cross-border flows and presence of foreign-owned banks may amplify the effects, according to the authors.

The independent variables are ranged into two types of bank regulation and institutional supervision quality. The classification is based on broad categories of macro-prudential policies as used by several studies. This (IMF 11/238) classification allows for merging with data on international banking flows compiled by the BIS extracting differing implications of the policies on international banking flows in the ASEAN countries. Other reasons for selecting the variables are listed in Table 9.

Table 9

Variables Selection

\begin{tabular}{|c|c|c|c|c|}
\hline No. & Broadly-defined types ${ }^{*}$ & & & \\
\hline 1 & $\begin{array}{l}\text { Banking regulation } \\
\text { environments }\end{array}$ & 1 & $\begin{array}{l}\text { Lending standards } \\
\text { restrictiveness }\end{array}$ & $\begin{array}{l}\text { Through information-sharing and coordination of bank } \\
\text { supervision. }\end{array}$ \\
\hline 2 & $\begin{array}{l}\text { Institutional supervision } \\
\text { quality/market } \\
\text { infrastructures }\end{array}$ & 1 & Capital regulation & \\
\hline & & 2 & Reserve requirements & $\begin{array}{l}\text { Gray (2011) stated, in his working paper Central Bank Balances } \\
\text { and Reserve Requirements, that the purposes of reserve } \\
\text { requirements are to provide protections against both liquidity and } \\
\text { solvency risks ("prudential purpose"), and reserve requirements } \\
\text { are used by central banks to impact growth of monetary policy and } \\
\text { inflation ("monetary control purpose"), and "liquidity } \\
\text { management purpose". The variable captures the current state of } \\
\text { the provisions of credit in the ASEAN region attributed to massive } \\
\text { banking outflows. } \\
\text { Further, Reinhardt and Sowerbutts (2015) found that they are } \\
\text { applied as main tools to control credit growth in emerging markets. }\end{array}$ \\
\hline No. & Control variables & & & \\
\hline 1 & Financial liberalization & & Interest rate defence & $\begin{array}{l}\text { The country has liberalized its currency policy significantly in the } \\
\text { last two decades following the de-pegged of its currency the } \\
\text { Ringgit against other currencies. This was done to adjust the } \\
\text { Ringgit to the prevailing environment of weak commodity prices. } \\
\text { In this respect, Obstfeld (2014) observed that countries that do not } \\
\text { peg their exchange rates insulate their financial sector from } \\
\text { potential vulnerabilities in the external economic environment. }\end{array}$ \\
\hline 2 & $\begin{array}{l}\text { Accommodative } \\
\text { monetary policy }\end{array}$ & & $\begin{array}{l}\text { Low interest rate to } \\
\text { assess the impact on } \\
\text { bank leverage }\end{array}$ & $\begin{array}{l}\text { Dell'Ariccia et al. (2013) constructed an ex-ante measurement } \\
\text { using loan data on the riskiness of loans to study the impact of low } \\
\text { interest rates on bank risk-taking. The authors argued that this way } \\
\text { it allows measurement of the risk attitude of banks at the time a } \\
\text { loan is issued, rather than on ex-post loans performance which } \\
\text { could be affected by subsequent events. }\end{array}$ \\
\hline 3 & Growth opportunity & & $\begin{array}{l}\text { Where each country is } \\
\text { viewed with } \\
\text { time-varying growth } \\
\text { opportunities }\end{array}$ & \\
\hline
\end{tabular}

Note. ": The categorization is based on broadly defined types of macro-prudential measures as used by several studies including Reinhardt and Sowerbutts (2015) of the Bank of England. The classification allows us to merge with data on international banking flows compiled by the BIS extracting differing implications of the policies on international banking flows. 


\section{Concluding Remarks}

For a future study, it is to dissect to uncover the effects of the shifts from debt finance to equity finance, and how this shift may achieve financial stability. Also, to disentangle the bank leverage into two portions, the deposits raised generally from issuance of debt liabilities to foreign investors and banks' owner equity or capital. Also, a future study may incorporate to measure geopolitical risks - as it is until now it is viewed as regionalized and idiosyncratic but in an inter-connected financial market - political dislocations do have financial consequences. Also, a future study may assess the weakening ASEAN currencies effects on interest exchange rates across the ASEAN economies - inflicting by the devaluation of the Chinese Yuan following the slowdown in the Chinese economy. The reason is that the world second biggest economy, China, accounts for $25 \%$ of the Philippines' total trade, followed by Thailand and Malaysia at about $22 \%$, and $19 \%$ of Indonesia total trade is with China. Because ASEAN banks have funding disadvantage due to capital outflows, future studies may also include measuring whether this induces an increase in lending by non-ASEAN foreign banks countries, and if so why? Furthermore, looming further cuts in the interest rates across ASEAN countries - while the United States Federal Reserve is impending further increases in interest rates in 2016 - there are concerns on the effects of the increases in the interest rates on international capital flows, would remained. The biggest fear is that there could be even more bank outflows spurring from the ASEAN economies to the United States, which presumably will yield higher returns. However, Sidhu (2015) foresaw that the emerging economies stance will diverge from that of the United States and instead, it will be more influenced by the economic and monetary cycles in China than in the past. The divergent monetary policies across the United States, Europe, and Japan could pose some immense challenges. Against the backdrop of surge in international bank outflows, the ASEAN banks could feel the pressure from debt servicing capacity of businesses, leaving the ASEAN banks exposed to risks of bad loans. The BIS has noticed an increase in foreign currency debt accumulated by borrowers in ASEAN markets. BIS found a disturbing decline in profitability among ASEAN borrowers, suggesting a rising risk of defaults. Therefore, a future study may extend to test whether the effect of non-performing loans rate depends on exchange rate, enriching the regression model by including an interaction term of exchange rate and non-performing loans. All in all, future studies may be extended to assess corresponding effects arising from the shift in the pattern of financial intermediation from the banking sector to the capital market.

\section{References}

Aiyar, S., Calomiris, C. W., \& Wieladek, T. (2012). Does macro-pru leak? Evidence from a UK policy experiment. NBER Working Paper No. 17822, pp. 1-53.

Allen, F., Carletti, E., \& Marquez, R. (2011). Credit market competition and capital regulation. Review of Financial Studies, 24(4), 983-1018.

Almekinders, G., Fukuda, S., Mourmouras, A., \& Zhou, J. (2015). ASEAN financial integration. International Monetary Fund Working Paper No. 15/34, pp. 1-43.

Asian Development Bank. (2015). Key indicators for Asia and the Pacific 2015 (46th ed.). Retrieved from http://www.adb.org/sites/default/files/publication/175162/ki2015.pdf

Astriana, F. (2015). Challenges facing Asean banking integration. The ASEAN Studies Program, the Habibie Center, Jakarta, Indonesia, pp. 1-2.

Bruno, V., Shim, I., \& Shin, H. S. (2015). Comparative assessment of macroprudential policies. Bank for International Settlement (BIS) Working Paper No. 502, pp. 1-53. 
Caprio, G., \& Klingebiel, D. (2003). Episodes of systemic and borderline financial crises. The World Bank Research Dataset. The World Bank, Washington, D.C.

CARI Captures. (February 10, 2016). Retrieved from http://www.cariasean.org/Captures/CARI_Captures252_10February2016.pdf

Dell'Ariccia, G., Laeven, L., \& Suarez, G. (2013). Bank leverage and monetary policy's risk-taking channel: Evidence from the United States. International Monetary Fund (IMF) Working Paper 13/143, pp. 1-40, Unpublished Manuscript.

Fantom, N., \& Serajuddin, U. (January 12, 2016). Classifying countries by income: A new working paper. The World Bank.

Goldstein, M., \& Turner, P. (1996). Banking crises in emerging economies: Origins and policy options. Bank for International Settlements (BIS) Economic Papers No. 46, pp. 1-67.

Gray, S. (2011). Central bank balances and reserve requirements. International Monetary Fund (IMF), Working Paper No. 11/36, pp. 1-55.

Hale, G., \& Arteta, C. (2009). Currency crises and foreign credit in emerging markets: Credit crunch or demand effect? European Economic Review, 53(7), 758-774.

Hmili, R., \& Bouraoui, T. (2015). Early warning indicators of banking crisis in Asian countries. Expert Journal of Finance, 3(1), $1-8$.

Houston, J. F., Lin, C., \& Ma, Y. (2012). Regulatory arbitrage and international bank flows. Journal of Finance, 67(5), 1845-1895.

Iamsiraroj, S., \& Doucouliagos, H. (2015). Does growth attract FDI? Economics E-Journal, Discussion Paper No. 2015-18, Kiel Institute for the World Economy, pp. 1-41.

Jeanne, O. (2014). Macroprudential policies in a global perspective. National Bureau of Economic Research (NBER) Working Paper No. 19967, pp. 1-32.

Kalemli-Ozcan, S., Papaioannou, E., \& Perri, F. (2013). Global banks and crisis transmission. Journal of International Economics, 89(2), 495-510.

Lim, C., Columba, F., Costa, A., Kongsamut, P., Otani, A., Saiyid, M., Wezel, T., \& Wu, X. (2011). Macroprudential policy: What instruments and how to use them? Lesson from country experiences. International Monetary Fund (IMF) Working Paper No. 11/238, pp. 1-84.

Matemilola, B. T., Bany-Ariffin, A. N., \& Muhtar, F. E. (2015). The impact of monetary policy on bank lending rate in South Africa. Borsa Istanbul Review, 15(1), 53-59.

Mohanty, M. S. (2015). What do new forms of finance mean for EM central banks? Bank for International Settlements (BIS) No. 83, pp. 1-8.

Moshirian, F., \& Wu, Q. (2009). Banking industry volatility and banking crises. Journal of International Financial Markets, Institutions and Money, 19(2), 351-370.

Obstfeld, M. (2014). Trilemmas and tradeoff: Living with financial globalization (Unpublished manuscript). Paper for the Asian Monetary Policy Forum, Singapore, pp. 1-50.

Ongena, S., Popov, A., \& Udell, G. F. (2013). "When the cat's away the mice will play": Does regulation at home affect bank risk-taking abroad? Journal of Financial Economics, 108(3), 727-750.

Reinhardt, D., \& Sowerbutts, R. (2015). Regulatory arbitrage in action: Evidence from banking flows and macroprudential policy. Bank of England Working Paper No. 546, pp. 1-36.

Sidhu, J. S. (December 19, 2015). After the fed rate hike. StarBizWeek, p. 16.

Were, M., \& Wambua, J. (2014). What factors drive interest rate spread of commercial banks? Empirical evidence from Kenya. Review of Development Finance, 4(2), 73-82.

World Bank. (2015). The World Bank annual report 2015 (pp. 1-57). Retrieved from http://www.worldbank.org/en/about/annual-report

Zdzienicka, A., Chen, S., Kalan, F. D., Laseen, S., \& Svirydzenka, K. (2015). Effects of monetary and macroprudential policies on financial conditions: Evidence from the United States. International Monetary Fund (IMF) Working Paper WP/15/288, pp. 1-29. 